\title{
과테말라에 대한 대외원조 현황
}

\section{I . 개요}

과테말라 경제기획청(SEGEPLAN)이 최근 발표한 자료에 의하면 작년도 과테말라에 대한 대외원조 (bilateral)는 총 5,500만불로서 최근 10 년간 가장 낮 은 실적을 기록하였는 바, 이는 양자간 대외원조액의 감소 및 다자차원의 원조액 증가에 그 원인이 있는 것으로 분석됨.

\section{II. 양자간 대외원조}

ㅁ 1996 2004년간 과테말라에 대한 양자간 대외원 조액은 우리나라를 포함 18 개국에서 14 억불을 제 공하였는 바, 이 중 미국, 일본, 대만 및 독일이 전 체의 $81 \%$ 에 해당하는 원조를 제공하였음.

- 미국 5.1억불, 일본 3.6 억불, 대만 1.4 억불, 독일 1.3 억불
- 우리나라는 동 기간동안 185 만불을 제공하여 18 개국 중 15 위에 해당

- 1996년의 평화협정 체결 직후인 1997 99년 간 에는 평화협정 이행을 목적으로 한 대외원조가 주류를 이뤄 연평균 2 억불 이상이 유입되었으 나, 2004 년도 실적은 이의 $1 / 4$ 에도 못 미치는 정도에 그쳤음.

- 이는 평화협정이 어느 정도 이행됨에 따라 원조 공여국의 관심이 여타 지역으로 전환됨에 따라 나타난 현상으로 보이며, 최근 공여되는 원조도 소외지역 개발, 빈곤타파 등을 목적으로 하고 있음.

\section{III. 다자차원의 원조}

ㅁ양자차원의 대외원조가 감소되는 반면 다자차원 의 대외원조는 상당수준을 꾸준히 유지하여 
1996 2004년간 총 21.5 억불을 기록하였음.

- 미주개발은행(IDB), 국제부흥개발기구 (IBRD), 중미경제통합은행(CABEI), 유럽연합 (EU), 유엔개발계획(UNDP)을 통한 원조가 주를 이루고 있어, 이들 5 개 단체의 원조가 전 체의 $91 \%$ 를 차지

[자료:주과테말라 대사관] 